\title{
Yazınsal Etik ve Politika: Bilge Karasu Romanına Konuksever Bir Yaklaşım*
}

\author{
Berat $\left.A c ̧\right|^{* *}$
}

Öz: Felsefe ve edebiyat arasındaki ilişkiyi düşünme yollarından biri, konukseverlik düşüncesidir. Söz konusu düşünce, felsefî açıdan, Emmanuel Kant ve Emmanuel Levinas'tan geçerek Jacques Derrida tarafından geliştirilmiştir. Konukseverlik, Derrida'nın tanımıyla, olanaksızlığa yakın bir olanaklılık içinde var olabilen bir düşüncedir. Bu düşüncenin alt yapısını etik ve politika oluşturmaktadır. Elinizdeki makale Bilge Karasu'nun romanlarını (Gece ve Kılavuz) Derrida'nın konukseverlik düşüncesiyle birlikte düşünmeyi amaçlamaktadır. Konukseverlik düşüncesi Karasu romanlarında hem etik hem de politika boyutuyla ele alınabilir. Konukseverlik düşüncesi ve Bilge Karasu romanları arasındaki ilişki iki aşamada incelenebilir. İlk aşamada Gece ve Kılavuz romanlarındaki karakterler arası ilişkide konukseverlik düşüncesinin izleri aranacaktır. Bu ilişki, konukseverlik düşüncesinin etik ve politika boyutlarıyla ele alınacaktır. İkinci aşamada, söz konusu romanlardaki anlatıCı, muhayyel muhatap, yazar ve okur boyutlarıyla yani yazınsal konukseverlik açısından söz konusu romanlar ele alınmaktadır. Konukseverlik düşüncesinin etik boyutu daha çok Kılavuz ile birlikte düşünülürken politika boyutu da Gece ile birlikte düşünülecektir. Yazının temel iddiası Bilge Karasu'nun yazınsal konukseverlik düşüncesiyle ele alınabilecek romanlar kaleme almış ve konuksever bir yazar olduğudur.

Anahtar Kelimeler: Bilge Karasu, Derrida, Konukseverlik, ev-metin, yazınsal konukseverlik

\begin{abstract}
One of the ways to think about the relationship between philosophy and literature is hospitality. Hospitality, philosophically, developed by Jacques Derrida, passing through Emmanuel Kant and Emmanuel Levinas. Hospitality, defined / conceptualized by Derrida, is a thought that can exist in a possibility that is almost impossible. Ethics and politics are underlying thoughts of hospitality. This article, tries to think Bilge Karasu's novels (Gece and KIlavuz) via Derrida's thought of hospitality. The thought of hospitality can be handled with respect to both ethics and politics. The relationship between hospitality and Karasu's novel can be examined on two levels. On the first level, traces of the thought of hospitality in the relationship between characters will be analyzed in Gece and KIlavuz by Bilge Karasu. This relationship will be examined both in its ethical and political aspects. On the second level, these novels will be evaluated according to literary hospitality, that is the novels will be examined by the relationships between the narrator(s), narratee, the writer and the reader. The ethical aspect of the hospitality will be thought related to KIlavuz and political dimension of hospitality will be examined via Gece. The main argument of this article is that Bilge Karasu have written novels that can be analyzed with the thought of hospitality and Karasu is a hospitable writer.
\end{abstract}

Keywords: Bilge Karasu, Derrida, Hospitality, Home-text, literary hospitality

* Bu makale Bilim ve Sanat Vakfında 4 Haziran 2008 yılında sunulmuş bir bildiriye dayanmaktadır. Bu makalenin yazım aşamasında değerli katkılarını sunan ve konuyu benimle tartışma nezaketinde bulunan değerli dostlarım Fatime Yavuz Açı, Özkan Gözel, Doğan Ince, Ümit Aksoy ve Fatih Altuğ'a teşekkür ederim.

** Yrd. Doç. Dr., İstanbul Şehir Üniversitesi Türk Dili ve Edebiyatı Bölümü.

AtıfO: Açıl, B. (2010). Yazınsal Etik ve Politika: Bilge Karasu Romanına Konuksever Bir Yaklaşım. Insan ve Toplum, 1 (1), 7-23. 
Felsefenin günlük hayatla ne gibi bir ilişkisi vardır? Kuram ve yaşam birbirinden tamamen ayrı iki alan olarak mı yoksa birbirini bütünleyen, açımlayan ve destekleyen ilintili iki alan olarak mı algılanmalıdır? Bu soruların yanıtını kuram ve yaşamın iç içe irdelenebileceği konukseverlik düşüncesi ve konukseverlik düşüncesinin Bilge Karasu romanlarıyla ilişkisi çerçevesinde ele almaya çalışacağım. Kuram ve yaşamın, diğer kuramlara oranla daha fazla kesiştiği konukseverlik kuramı, Bilge Karasu romanlarını anlam(landırm)a uğraşında eleştirmenlere yeni birtakım imkânlar açıyor görünmektedir. Dolayısıyla elinizdeki makale bir yandan kuramsalken öte yandan bir uygulama denemesidir.

Bu makalede, Bilge Karasu'nun Gece (2004) ve Kılavuz' (2006) adlı romanları için bir "kılavuz" bulmaya çalışılacaktır. Makalede söz konusu "kılavuz"un da "konukseverlik" düşüncesi olduğu iddia edilecektir. Bu makalede genel olarak Derrida'nın konukseverlik düşüncesini irdeledikten sonra, Gece ile Kılavuz'a konukseverlik bağlamında odaklanmayı deneyeceğim. Yazınsal etik konusuna daha çok Kılavuz ele alınırken, yazınsal politika konusuna da (yine daha çok) Gece ele alınırken değinilecektir.

Konukseverlik düşüncesi, her ne kadar felsefi açıdan Levinas² ile bütünleşmişse de konu Derrida'nın Levinas'tan çokça etkilenmiş konukseverlik kuramı bağlamında tartışılacaktır. Bu tartışmadan önce, Levinas ve Derrida'nın konukseverlik düşünceleri arasındaki temel farklara işaret etmek gerekir: Levinas'ın konukseverlik göstereceği, gösterilmesi gerektiğini düşündüğü yabancı, öteki, insandır ${ }^{3}$ fakat Derrida'da yabancı veya öteki insan olmak zorunda değildir. Derrida için yabancı, adını bile söylemeden gelen biriyken "Levinas için, yabancı adını bile ifşa etmeden kalmaya gelen biri değildir" (Bernasconi, 2004: 115). Derrida ve Levinas arasındaki diğer bir fark şudur: Levinas'ta "ötekine boş elle gidilme"diği için ötekiyle ilişki maddi bir dolayımdan geçer; bu yüzden konukseverlik için ötekine sunulacak bir şey (ötekine açılacak, sunulacak bir ev) gerekliyken Derrida'da böylesi bir gereklilik yoktur. İkisi arasındaki üçüncü fark ise etikten adalete yani politikaya geçiş aşamasıdır: Levinas, ötekiye karşı etik davranılması gerektiğini ileri sürer. Adalet ve politika üçüncü kişiyle ilişki esnasında devreye girer. Levinas'ın aksine Derrida'da öteki ve üçüncü arasında bu kadar keskin bir ayrım yoktur. Levinas için "dilin özü dostluk ve konukseverliktir" (Levinas, 1969: 305). Bu düşünce Derrida tarafından da onaylanır görünmektedir. Tartışılan konu bağlamında oldukça önemli olan bu yargıya yazınsal konukseverlik bahsinde geri dönülecektir.

1 Bilge Karasu'nun öykülerindeki -özellikle "Avından El Alan” öyküsü- konukseverlik konusunu başka bir makalede tartışmayı planladığım için bu makaleyi sadece Karasu'nun romanlarıyla kısıtladım.

2 Levinas'ın konukseverlik kuramı için bk. Levinas, (2003: 74-76); ayrıca konukseverlik düşüncesinin ontolojik ve fenomenolojik kökenlerinin Levinas ve Derrida'nın konukseverlik düşünceleriyle karşılaştırılması için bk. Direk (1998: 193-198).

3 Levinas'ta konukseverlik düşüncesinin bu bağlamda tartışıldığı bir makale için bk. Bernasconi (2004). Söz konusu makalede yazar, Levinas'ın konukseverlik fikrini Heidegger ile ilişkilendirir (bk. Bernasconi, 2004: 119-121). 
Bu bağlamda düşünüldüğünde Derrida, konukseverliği radikalize eder ve tüm insanIığa teşmil eder. Girişte sorulan soruların yanıtı olarak şunu söylemek mümkündür: Kendisi de mülteci olan Derrida'nın konukseverlik düşüncesini irdelemesi çok da aykırı gibi görünmemektedir çünkü Derrida, konukseverlik kuramını mülteci sorununu ele almak için sorunsallaştırmış gibi görünmektedir. ${ }^{4}$ Derrida'nın Of Grammatology, Writing and Difference (1967) gibi ilk eserleriyle, seksenlerin sonundan 2004'teki ölümüne değin işlediği; mesihsellik, konukseverlik, dostluk, arkadaşlık, nezaket, armağan, söz verme, davet, sorumluluk, sır gibi konular arasında bir çelişki var gibi görünür. Fakat daha dikkatli bakıldığında Derrida'nın tüm yazdıklarının, aslında, bu gibi konuları tartışmak için zemin hazırlamaya yönelik olduğu iddia edilebilir. Derrida'nın kendisi de bu fikri destekler görünmektedir: "Ben ilk metinlerimin, (hadi bunlara daha akademik ya da felsefi olarak daha güven verici metinler diyelim) aynı zamanda, sonraki metinlerimin söylemsel ve teorik (temel ve kurucu demiyorum) koşulu, geri döndürülemeyecek ölçüde zorunlu koşulu olduklarına inanıyorum." (Derrida, 1998: 128). Derrida'nın konukseverlik hakkında yazması da söz konusu "söylemsel ve teorik koşul"a dayanmaktadır denebilir.

"Konukseverliğin Düşüncesi" (1997) adlı makalesinde Zeynep Direk, Levinas ve Derrida'nın konukseverlik hakkındaki düşüncelerini karşılaştırır. Söze Derrida'nın 1997 yılında Boğaziçi Üniversitesinde konukseverlikle ilgili yaptığı konuşmayla ("Konukseverliğin Açmazları") başlayan Direk, şöyle yazar: "Bu konuşma, bir KantLevinas karşılaştırmasından yola çıkarak, etik ile politika arasındaki geçişi düşünmenin, barış ile savaş fikirlerinin basit ve problematik karşıtıklarının ötesindeki ilişkilerinin yapılarını sorgulamanın fırsatını aramaktaydı." (Direk, 1997: 11). Buradaki etik ve politika vurgusu önemli çünkü konukseverliğin ilkin etik bir mesele olarak görünmesine karşın politikayla da yakından ilişkili olduğunu göz ardı etmemek gerekir. Derrida'nın söz konusu konuşması daha sonra Pera, Peras, Poros (1999) adıyla yayımlandı. Derrida, bu yazısında konukseverliğin, daha doğrusu mutlak konukseverliğin, işleyişini açıklar: “Konukseverlik kendini yok etmekten, 'başka bir deyişle kendini olanaksız olarak üretmekten, yalnızca olanaksızlığı koşuluyla olanaklı olmaktan' ya da kendisini kendisinden korumaktan, bir biçimde kendini bağışık kılmaktan yani tam anlamıyla uygulandıkça kendi kendisinin yapısını sökmekten başka elinden bir şey gelmeyen, kendi içinde çelişkili bir kavram ve deneydir." (Derrida, 1999: 48). Çelişki şurada yatmaktadır: "Konukseverlik yabancı olarak başkasına gösterilmelidir. Ancak başkası yabancı olarak belirlendiğinde işin içine aile, ulus, devlet, yurttaşlık gibi koşulluluk çemberleri girer." (Derrida, 1999: 54). Burada iki önemli meseleye değinilir. Birincisi, konukseverliğin kime gösterileceği; ikincisi, yabancının neye göre tanımlanması gerektiği. Derrida mutcesini irdelemesinin arkasında sömürgecilik yatarken Derrida da mülteci sorununu tartışmak için bu konuya eğilmiştir. 
lak konukseverliğin olanaksızlığı çerçevesinde olanaklı olduğunu söylerken aslında bu çelişkiyi kast eder görünmektedir: Mutlak konukseverlik sadece yabancıya gösterilmelidir (Bu arada yabancının sadece insan olarak düşünülmemesi gerektiğini belirtmek gerek: Yeri geldiğinde melek gibi insan üstü veya dışı varlıklar olabileceği gibi hayvanlar da olamaz mı diye de sorar Derrida. -Sorunun bağlamından "olmalı" cevabını verdiği anlaşıımaktadır.-) Derrida, konukseverliğin, aynı zamanda, kural dışı olması yani etik olması gerektiğini düşünmektedir. Eğer bir şart veya kural varsa orada etikten veya konukseverlikten söz etmek mümkün değildir; bu, olsa olsa kural veya yasa olur ki yapılan kurala veya yasaya uymaktan başka bir şey olmaz. Derrida, Yapıbozum ve Pragmatizm (Chantal, 1998: 136) adlı kitapta şöyle yazar: "Eğer görev, kategorik buyruk ile belirlenebilir bir özne arasındaki basit bir ilişki olarak kavranıyorsa, o zaman görevden kaçılıyor demektir." Burada Derrida'nın “ 'Dostluğa' ya da 'nezakete' ilişkin bir davranış, yalnızca bir ritüel kuralının yerine getirilmesinden ibaretse, bu ne dostane ne de nâzik bir davranış olacaktır." (Derrida, 2008: 22) sözünü anımsamakta fayda var. Tartışmanın çıkış noktasına dönüldüğünde, sorulan sorular baki: Konukseverlik göstereceğimiz yabancıyı nereden bilebiliriz? Birini yabancı olarak belirleme kıstasları nelerdir? Yukarıda alıntılandığı gibi "aile, ulus, devlet, yurttaşıık" gibi kıstaslar devreye girer ki bu kıstaslar, kıstas oldukları için zaten yani kategorik olarak, koşulluluk bildirirler. Dolayısıyla tanım gereği çelişkili bir durumla karşı karşıyayız. Koşulsuz olması gereken mutlak konukseverlikte konukseverliğin muhatabını "yabancı" olarak nasıl belirleriz? Ailemizden, ulusumuzdan, devletimizden yani ister kan ister ulus, yurttaşlık, devlet gibi tarihsel kurgularımızdan kaynaklı, yabancı olarak tanımlanmayan birine konukseverlik gösteremeyiz. Dolayısıyla dil ve kültür ortaklığı, yabancılığı ortadan kaldıran unsurlardır. Of Hospitality (2000) adlı kitabında, bu konuyla ilgili olarak Derrida şöyle yazar: "Levinas'ın başka bir bakış açısından söylediği gibi dil, konukseverliktir. Yine de mutlak, hiperbolik, koşulsuz konukseverliğin askıya alınan dilde, bir şekilde belirlenmiş bir dilde ve hatta ötekini işaret etmede var olup olmadığından şüphe etmeliyiz.. ${ }^{5}$ (Derrida ve Duformantelle, 2000: 135). Mutlak konukseverliğin açmazından kurtulmanın en temel yolunu Derrida "gelene bir şey sormamak" olarak gösterir. Bu durumda "dil, ulus, aile" gibi konukseverliği askıya alabilecek unsurların bilgisinden kaçınılmış olur. Yine de bu, bir koşulluluk cümlesidir. Bunun farkında olan Derrida "bir yandan yasa, görev ve hatta politikadan vazgeçen/onlardan bağımsız olan koşulsuz konukseverlik ve öte yandan yasa ve görevle sınırlanan konukseverlik arasındaki çelişki bizi daima tehdit edecektir. Onlardan biri daima diğerini bozabilir ve bu ifsat kapasitesi azaltılamaz olarak kalır." (Derrida, 2000: 135) der.

Görüldüğü gibi Derrida, konukseverliği olabildiğince geniş tutmaya çalışır. Direk, bu konuyla ilgili şöyle yazar: "Marks'ın Hayaletleri, Derrida'da konukseverliğin, yüzün sınırlarının ötesine doğru, yaşayan her şeye ve gelenekte yaşayan ölülere, hayaletle- 
re doğru genişlediği izlenimini uyandırır. Ziyaretçi, bir insan, bir hayvan, bir tanrı, bir hilkat garibesi ve hatta bir makine, bir hayalet olabilir." (Direk, 1997: 35-36). Bu kadar geniş tanımlandığında Derrida'nın neden mutlak konukseverliğin olanaksızlık içinde olanaklı olabildiğini söylediği daha rahat anlaşılabilir. Bir hayvana, hilkat garibesine ya da daha zor olanı bir hayalete karşı konukseverlik nasıl bir deneyim olabilir? Derrida'nın koşulsuz, mutlak, kurala uymayan, yapı çözüme uğratılamayan bir adalet, bir etik çerçevesinde konuyu tartıştığını akılda tutmak gerek. Etiğin de konukseverlik gibi olanaksıza yakın bir deneyim olduğu söylenebilir. Daha önce ifade edildiği üzere hem Levinas hem de Derrida'ya göre etiğin herhangi bir koşulu veya yasası olamaz. Nezaket örneğinde olduğu gibi etik bir kurala zorunlu olarak uymak, etik bir davranış değildir; olsa olsa bir kurala uymaktan ibarettir; bu da aslında, eylemde bulunmamak demektir. Michael Naas, "Jaques Derrida ve Konukseverlik Sorusu" adlı makalesinde Le Monde'daki bir söyleşi sırasında Derrida'nın "Gelen kişiye nasıl muamele edilmelidir?" biçimindeki soruya şu yanıtı verdiğini aktarır: "Saf konukseverlik arrivant'ı, yani gelen kişiyi, hiçbir koşul öne sürmeden, hakkında adı dâhil kim olduğuna dair hiçbir şey bilmeden veya bir kimlik belgesi sormadan buyur etmeye dayanır." (Naas, 2006: 239). Burada gelenin, konuğun tanınmaması, kimi kuşkulara yol açabilir: Gelenin, konuğun düşman olmayacağını, düşmanca davranmayacağını, ev sahibinin evini ve otoritesini elinden almayacağını kim garanti edebilir? Böylesi bir tehlike karşısında da konuksever olmak gerekir mi? Derrida'ya ve onun "olanaksıza yakın olanaklılık içindeki konukseverlik düşüncesine göre yanıt, "evet"tir. Mutlak konukseverliğin, etiğin zorluğu tam da burada ortaya çıkmaktadır. Naas, “Konuseverlik, Derrida'nın önerdiği gibi, ancak bu riskin bize, ailelerimize, ülkelerimize, hatta tam da bunları tanımlamamızı sağlayan özdeşlik ilkesine yönelen bir riskin bedeline kadar genişletilebilir." diye yazar (Naas, 2006: 246). Buradaki özdeşlik vurgusu önemlidir. Levinas'tan da hatırlanacağı gibi "öteki"yle ilişki onun "başkalığı"nı koruyarak, kapatmadan, sınırlamadan yani onu özdeşleşmeye zorlamayarak mümkündür. Zira etik, başkasıyla ilişki sırasında ortaya çıkar. Levinas başkasıyla ilişkinin zorunlu olarak üçüncünün de devreye girmesini sağlayacağını ve bu durumda politikanın düşünülmeye başlanacağını söyler. Levinas ve Derrida'nın konukseverlik, dolayısıyla etik ve politika konusundaki düşünceleri kısaca serimlendikten sonra Bilge Karasu romanında etik ve politikanın işleyişine konukseverlik bağlamında bakılabilir. Karasu'ya evvel bu makalenin temel amacının konukseverlik düşüncesinden hareketle Karasu romanları tartışmasının nasıl yürütülebileceğini sorgulamak olduğunu tekrar vurgulamakta fayda var.

Bilge Karasu romanlarında üç çeşit konukseverlikten söz etmek mümkündür: İlki, burada sadece Karasu'nun romanları ele alınacağı için, ayrıntısına girilmeyecek olan "Avından El Alan" öyküsündeki ölümcül/ölümüne konukseverlik; ikincisi, Kılavuz romanındaki gerçek mi düş mü olduğu anlaşılamayan belirsiz konukseverlik; üçüncüsü, Gece romanındaki konukseverlik rüyası veya rüyada konukseverlik (konukseverlik ütopyası da denebilir)tir. Bu makalede son ikisi ele alınacaktır. 
Kılavuz doğrudan doğruya konukseverliği işlemek için yazılmış gibidir. Olayların çoğu tek bir evde geçmektedir. Olaylar dört ana karakter etrafında şekillenmektedir: Uğur, İhsan, Mümtaz Bey ve Yılmaz Bey. Turunçlu'daki evin sahibi Yılmaz Bey'dir. Mümtaz Bey, Yılmaz Bey'in amcası kalıcı konuk, Uğur Mümtaz Bey'e refakat etmek için gelmiş olan geçici konuk, İhsan da daha çok Uğur'la eşcinsel göndermelerle dolu arkadaşlığı ve Yılmaz Bey'in sadık taksicisi olarak giden-gelen konuk. Yılmaz Bey'i konukseverlik bağlamında ele aldığımızda Derrida'nın sözünü ettiği konukseverlik idealine yakın bir ev sahibiyle karşılaşmaktayız. Yılmaz Bey ev sahibi olmasına ev sahibidir ama tüm roman boyunca Uğur'la iş görüşmesi yaptığı süre ve sonlara doğru Mümtaz Bey, Uğur ve İhsan'ı Ankara'ya gidecekleri zaman uğurlamak için eve geldiği zaman dışında evde kalmaz. Evde uyuduğuna ise rastlanmaz. Diğerleri evi ondan daha fazla kullanmakta, konuk olduklarını, neredeyse gidinceye kadar, anımsamamaktadırlar.

Uğur, eve isminin bile sorulmadığını sanarak kabul edilir. Daha sonraki açıklamalarla bu sanı silikleştirilir ama Uğur, onunla beraber okur olarak biz de, öyle sanırız. En azından isminin sorulup sorulmadığından emin olamayız. Eve kabul edildikten sonra Uğur, belki de konukseverlikten tedirginlik duyar. "İmza da atmadım" (Karasu, 2006: 16), "'Kimsin, nesin', yok" der kendi kendine. Belli bir noktadan sonra yeni yaşamına alışmış görünen Uğur, taksi şoförü ìhsan'la eve ilk geldiklerinde ev sahibi gibi kapıyı açar, İhsan'ı buyur eder, ona kahve pişirir. Uğur da Yılmaz Bey gibi İhsan'a henüz ismini sormamıştır. Yani aynı zamanda, kendini kendi evinde gibi hisseden Uğur'un İhsan'a karşı sergilediği konukseverlikle karşı karşıyayız. Neden sonra "Affedersin kardeş, adın ne? Bu kadar konuştuk, adımızı söylemedik birbirimize. Ben, Uğur" (Karasu, 2006: 27) demek gelir aklına Uğur'un. Daha sonra İhsan ve Uğur duş alırlar ve kendilerine ait olmayan havluyu çekinmeden kullanırlar. Uğur, "Yabancısı olduğum bir evde, kendim -en iyimser yorumla- konukken, konuk ağırlamağa kalkışmanın eğriliği doğruluğu üzerinde durmadım." (Karasu, 2006: 24) der. Bu evde sanki kimse kimseye konuk veya ev sahibiymiş gibi davranmıyor. Yılmaz Bey, o kadar ev sahibi gibi davranmıyor ki Uğur "Ev Yılmaz Bey'in, orası belli, orası kesin. Ama masa, sanki hep Mümtaz Bey'in olmuş." der. Söz konusu olan, Yılmaz Bey'in çalışma masasıdır. Romanın ortalarına doğru Uğur da kendini "konuk" olarak tanımlamaya başlar (Karasu, 2006: 56). Yılmaz Bey, Uğur'u toplamda iki kez görmüş, ikisinde de ona birer armağan vermiştir. İkinci armağanı, bir tablodur. Yılmaz Bey, Uğur'a onun bir kopyasını da kendine aldığını ve buraya asacağını, Uğur buraya geldiğinde burada evinden bir parça göreceğini söyler (Karasu, 2006: 82). Yılmaz Bey'in ikinci gelişinde Uğur da konukseverlikle ilgili düşüncelere dalar: "Ev sahibi değil de, saydığımız, biraz da çekindiğimiz bir konuk gelmiş gibiydi eve." (Karasu, 2006: 89) diye düşünür. Yılmaz Bey, kendi evinde konuk olarak görülebilecek, konukseverliğin muhatabı yani kendisine konukseverlik gösterilecek biri olarak görülecek kadar konuksever bir ev sahibidir. Bu da konukseverliğin etik olarak sınırlara vardııılmış hâli olarak yorumlanabilir. Ev sahibi, konuk ayrımları ortadan kalkmış- 
tır artık. Derrida'nın sözünü ettiği olanaksız olanaklılık bağlamında konukseverlik meydana gelmiş görünmektedir.

Romanın ya da taslakların, "palimpsest" gibi üst üste yazılmış, silinmiş, düzeltilmiş roman taslaklarının oluşturduğu veya oluşturamadığı daha doğrusu bilinçli olarak oluşturmadığı yazıların yani Kılavuz'un -anlatıcı olarak Uğur'u düşünürsek- yazılma nedeni de aslında etik bir muhasebedir. Uğur, ölmeden önce yeteri kadar ilgilenemediği arkadaşının ölümünden kendini bir şekilde sorumlu tuttuğu için "esrarengiz" düşlerini görmeye başlamış ve tüm anlatı boyunca alımlamalarını bu düşlerin izleri şekillendirmiştir. Kendini Amerika'da ölen arkadaşı Bülent'in ölümünden sorumlu tutmakta, düşünsel ya da duygusal olarak onu öldürdüğünü düşünmektedir. Uğur'un söz konusu eve gitmesinde Bülent'in rolü muğlak bırakılmıştır fakat Uğur, Yılmaz Bey'in kardeşi olan Bülent'in ölümünden kendini sorumlu tutmaktadır. Onun gözünden bakıldığında Yılmaz Bey, kardeşinin ölümünden sorumlu olan kişiyi, düşmanını evine buyur etmiştir.

Görüldüğü gibi Kılavuz'daki tüm karakterler konukseverliğin etik çerçevesi içinde ilişkiye girmektedirler. Anlatıcının öyküsünü anlatma serüveni bile etik bir muhasebe sonucunda başlamıştır. Kılavuz'un anlatıcısı ve kurgusal düzeyde kendi metninin yazarı olan Uğur'un metnini kaleme alması etik bir davranıştır. Anlatı düzeyinde İhsan ve Mümtaz Bey'le kurduğu ilişki de etiktir. Mümtaz Bey ve İhsan da konuk oldukları metne, etik birer konuk olarak müdahalelerde bulunmuşlar ve metni zenginleştirmişlerdir, çoğaltmışlardır. Kılavuz'un anlatıcısı Uğur'dur ve aynı zamanda metin içinde bir metin yazmaktadır. Üst kurmaca unsurlarının yoğun bir şekilde görüldüğü bu durumda Uğur'un yazdığı metin Mümtaz Bey ve İhsan'ın muhayyel muhatap olarak müdahaleleriyle şekillenmiştir. Füsun Akatlı (1997: 120) Kılavuz'da üst üste bin(diril)miş anlatı stratejisi hakkında şunları yazmaktadır:

Tabii bir yandan, sürekli olarak, bir "yazma" eyleminin söz konusu olduğu da unutulmamalı. Anlatı kişilerinden Uğur'un günlüğü anlatı boyunca "yazılmaktadır" ve Kılavuz'un kendisi de, o günlüğün versiyonlarından biri, muhtemelen sonuncusu ile özdeşleşmektedir.

Buradan yazar, okur, anlatıcı, muhayyel muhatap kavramlarının politika bağlamında işlendiğini iddia ettiğim Gece'ye geçilebilir. Gece, hem kelimenin gerçek anlamıla hem de yazınsal anlamıyla konukseverlik düşüncesinin etikten sonraki ikinci içerimi olan politikayla yakından ilintili, politika gözüyle okunabilecek bir kitaptır. Burada söz konusu kitaba konukseverlik düşüncesinin içerimlerinden biri olan (yazınsal) politika açısından yaklaşmaya çalışılacaktır. Yazınsal politika, konukseverlik düşüncesinin etikten sonraki adımı olarak da düşünülebilecek olan üçüncü kişinin devreye girdiği alanın edebî metinlerdeki görünümünü tanımlamak için kullanılmaktadır. Gece'de mutlak konukseverlik örneği 94., 98., 100., 102. ve 104. bölümlerde daha açık bir şekilde yer alır. Gecenin işçileri şehrin sokaklarını yeniden düzenlemişler ya da düzensizleştirmişlerdir. Hiçbir sokağın iki çıkışı yoktur. Her sokak sadece bir yere çıkar. Sokağın sonun- 
da bir caddeye ya da başka bir sokağa varıldığında caddenin veya sokağın diğer cadde veya sokaktan üç metre yukarıda veya beş metre aşağıda olduğu görülür. Dolayısıyla bir sokağın sonuna gelindiğinde gerisin geri başlanan yere yürümek gerekecektir. Bu durumda aranan bir yeri bulmak neredeyse rastlantıya kalmıştır. Hava karardıktan sonra dışarıda, sokaklarda kalmak da imkânsız hâle gelmiştir çünkü dışarıda kalanların başlarına çeşitli işler gelmektedir. Bu duruma çözüm neredeyse kendiliğinden bulunmuştur. Kimi sokaklarda, dışarıda kalanların sığınmaları için "konuk evi" denebilecek evler oluşmuştur. Anlatıcılarımızdan biri (Aşağıda bu konuya döneceğiz çünkü Cem İleri'nin Yazının da Yırtııverdiği Yer adlı çalışmasında (ileri, 2007) ayrıntılı olarak anlattığı gibi anlatıcı kendini dörde bölmüştür.) evini bulamayacağına karar verince ışık gördüğü bir eve sığınmak zorunda kalır. Gelen kişi, arrivant, içeriye buyur edilir, burada da isim sorulmaz. İçeride kırk-kırk beş kadar insan vardır. Ortada ev sahibi ya da ev sahibi gibi davranan birileri görünmemektedir. Yataklar yan yana dizilir ve insanlar öylece uyurlar. Beş bölüm boyunca anlatılan bu olayların bir düş olduğunu öğreniriz daha sonra. Bu anlatıya, dolayısıyla Karasu'nun "mutlak konukseverlik" düşü, daha doğrusu ütopyası (u-topos: olmayan yer) demek istiyorum. Karasu, mutlak konukseverliğin nasıl olması gerektiğini örneklemek istemiş gibidir. Kelimenin gerçek anlamıyla konukseverliğin Kılavuz ve Gece'deki tezahürlerine baktıktan sonra konukseverlik dolayımıyla söz konusu iki romandaki yazınsal etik ve politika konusuna geçebiliriz.

Bu kısımda yazınsal etik ve politika, yazınsal konukseverlik bağlamında ele alınmaya çalışılacaktır. Konukseverlik düşüncesi yazınsal konukseverlik bağlamında ele alınmadan önce, Derrida'nın da onaylar gibi göründüğü Levinas'ın "Dilin özü dostluk ve konukseverliktir." sözünü biraz açmakta yarar var. Levinas'a göre önemli olan söylemedir, söylenen değil. Dolayısıyla önemli olan, dil sayesinde kurulan bir ilişki biçimidir söyleme. Bu ilişki biçiminde söyleyen kadar söylenen (muhatab) de önemlidir. Bir dinleyen yoksa, söyleyen de anlamını yitirir. Söyleme ediminin ortaya çıktığı konuşma sırasında söz, arada gider gelir, dolaşır yani söz uçar "verba volant". Bu bağlamda düşünüldüğünde sözün sahibi yoktur. Söyleyen de dinleyen de, aslında, dile konuk olmuşlardır. Ev de ev sahibi de dildir. Burada Heidegger'in "Dil varlığın evidir." sözü anımsanabilir. Dolayısıyla konukseverlik gösteren dilin kendisidir, ${ }^{7}$ hepimiz dile konuğuz. Bu varsayımdan, temel malzemesi dil olan edebiyata dolayısıyla yazınsal konukseverliğe geçilebilir.

Konukseverlik zorunlu olarak bir konuk ve ev sahibini içinde barındırır yani ben ve öteki/başkası söz konusudur burada. Ben ve başkanın olduğu yer, etiğin alanıdır. Fakat Levinas'tan bu yana ben ve ötekinin olduğu yerde bir üçüncünün de devreye gire-

6 Bu çalışmayla ilgili ciddi bir eleştiri için bk. Özata Dirlikyapan (2008). Özata Dirlikyapan'ın haklı olarak gösterdiği gibi İleri, daha çok Gürbilek'ten esinlenmiş görünmekte, onun cümlelerini neredeyse aynen metnine almakta ve herhangi bir göndermede bulunmamaktadır.

7 Derrida'daki dil, öteki ve konukseverlik ilişkisi ile ilgili benzer bir yorum için bk. Stocker (2006: 33839). 
cek; bu durumda da adalet ve politika söz konusu olacaktır. Yazınsal konukseverlik gibi bir kavram ortaya atarken de etik ve politikanın ortaya çıkacağı bir düzlem tasarlamak gerekiyor. Peki, yazınsal dediğimiz zaman hangi failler devreye girer? En basit hâliyle yazar ve okurdur karşımızda olan. Anlatıbilimsel açıdan baktığımızda metinsel/ kurgusal bir nelikten söz edileceği için karşımıza çıkacak failler (narrator) anlatıcı ve (narratee) ${ }^{8}$ muhayyel muhataptır. Yazınsal konukseverlikte, dolayısıyla, yazarın okura karşı etik ve politik tutumundan söz etmemiz gerekecek.

İleri, konukseverliğin etik gibi bir anda var olabilen, o anlık bir şans olarak beliriveren ve hemen kaybolan yönünü yani zamansal yönünü odağa alarak Kılavuz'un zamanını irdelemektedir. Dahası İleri, Derrida'nın sözünü ettiği "konukseverlik yasaları" metinlerine Kılavuz'un da eklenmesi gerektiğini ileri sürer ki bence de doğru bir yaklaşımdır. Zira daha önce de belirtildiği gibi Karasu, bu romanda (Gece'de de) mutlak konukseverlik nasıl olmalıdır diye düşünüp metni öyle yazmış gibidir. İleri'nin iddiasının aksine Derrida'ya göre, etik her zaman vardır, bir anlık bir şans değildir. Her zaman "bir Öteki'yle ilişki içinde" olduğum için etik "hiçbir zaman olmamazlık edemez" (Stocker, 2006: 339). Illeri'ye göre "konukseverlik yasaları"na dâhil edilmesi gereken kitap Karasu'nun Kılavuzu'dur. Bu yargıya katılmakla beraber yargının eksik olduğunu düşünüyorum. Gece adlı romanın da bunlara dâhil edilmesi ve bu eserin de konukseverlik bağlamında okunması gerektiğini düşünüyorum. ${ }^{9}$

Derrida'nın sözünü ettiği konukseverlikte bir ev ve bir konuk vardır. Yazınsal konukseverlikteyse bir ev yani metin ve bir konuk yani okurdan söz etmek mümkündür. Fakat kurmaca alanından söz edildiği için yazar yerine anlatıcı, okur yerine de muhayyel muhatap kavramlarını kullanmak zaruridir. Ev sahibi de anlatıcıdır. Bu durumda anlatıcının ev sahibi olarak muhayyel muhataba yani konuğa karşı nasıl bir konukseverlik veya konuk sevmezlik gösterdiğine bakmak gerekecektir. Metnin anlatıcısı Uğur gibi görünüyor, yani elimizdeki Kılavuz'un anlatıcısı Uğur'dur, çünkü Uğur, en azından görünürde yaşadıklarını kaleme alıyor; bu durumda Mümtaz Bey ve İhsan, Uğur'un muhayyel muhatapları yani konuklarıdır. Uğur konuksever bir ev sahibi olarak Mümtaz Bey ve İhsan'a evini/metnini açar ve onların ev-metinde yaptıkları değişikliklere dokunmaz. Konuk evde istediği yere girip çıkabileceği, kendine kahve pişireceği, sofra hazırlayacağı, duş alacağı ve evin anahtarını taşıyabileceği gibi Mümtaz Bey ve İhsan da konuk oldukları metinde istedikleri tasarrufu yaparlar. Bundan böyle Uğur'un metnine ya da Kılavuz'a ev-metin de denebilir. ${ }^{10}$ Ev metin kavramı, konukseverlik düşünce-

9 Daha önce de dile getirildiği gibi bu makale Karasu'nun romanlarına yoğunlaşmaktadır. Karasu'nun diğer metinleri de bu açıdan değerlendirilmeye müsaittirler.

10 Türkçede çokça kullanılan bir deyim, söz konusu konukseverlik düşüncesini anlamakta faydalı bir kullanım olabilir: Yolgeçen hanı. Çünkü yolgeçen hanında ev sahibi-konuk ayrımı giderek silikleşmekte ve mutlak konukseverliğe doğru bir kayma hissedilmektedir. Gece'de mutlak konukseverlik 
sindeki failler ve kurmaca evrenindeki failleri birlikte düşünebilmeye imkân açtığı için önemli bir kavramdır. Mümtaz Bey ve İhsan ev-metinle ilgili tasarruflarda bulunurlar hatta Mümtaz Bey ve İhsan için ayrı ayrı ev-metinler vardır ve Uğur yani evmetnin sahibi onların yaptıkları değişikliklere hiç dokunmaz. Böylece metnin yapısı da değişir. Bu durumda şu soru anlamlı görünmektedir: Elimizdeki metin yani Kılavuz kime ait? Uğur'a mı, Mümtaz Bey'e mi, İhsan'a mı? Elimizdeki metin bir palimpsesti anımsatmaktadır. Üst üste bindirilmiş, silinip yeniden yazılmış ama alttaki yani silinmiş metnin de göründüğü/okunabildiği bir metindir, karşımızdaki. İleri (2007: 217), bu durumu şöyle açıklar:

“Karasu'nun yazısı orada değildir, yazının yerine başka bir şey, Uğur'un acemi yazısı seçilmiş, oraya yerleştirilmiştir. [...] Her sözcük sayısız olasılı̆ı̆ı taşır, metnin inceliverdiği ve bazı cümlelerin, sözcüklerin katmanlardan hangisine ait olduğunun anlaşılamadığı, birden fazla yere, birden fazla yazara, anlatıcıya ait olabileceklerini düşündüğümüz bölümlerle doludur kitap".

Yani metinler üst üste binmiş/bindirilmiş, hangi sözcüğün hangi anlatıcıya ait olduğu anlaşılamayan bir yok-metinle, bir ev-metinle karşı karşıyayız. Şöyle düşünülebilir: Eğer şu anda bir okur olarak elimizde, üzerinde Bilge Karasu / Kılavuz yazan, metis yayınlarından çıkmış bir kitap olmasaydı, Kılavuz diye bir kitabın hiç olmadığı söylenebilirdi ${ }^{11}$ çünkü her metin bir öncekini silmiştir. Bu durumu ilk tespit eden kişi olarak Nurdan Gürbilek (1995: 85), Karasu metinlerinin bitmemişliği hakkında şunları yazmaktadır:

Öykünün akıp gitmesine razı olmayan, metnin akışını iç içe, yan yana, alt alta getirdiği bir cümleyle, bir öyküyü başka bir öyküyle dengelemek isteyen; metni yan notlar, dipnotlar, ara notlarla parçalayan, dipnot düşen, dipnota dipnot düşen, tırnak içine alan, parantez açan, geriye dönen, araya giren Karasu; üzerinde ne kadar çok çalışmış olursa olsun, yazdıklarını hep taslakmış gibi, bitmemiş gibi, hiç bitmeyecekmiş gibi sunan Karasu. Elimizde bir metin var şimdi: Sürekli yeni baştan kurgulanmak, bozulup yeniden yapılmak, yeniden yontulup biçilmek istenen bir metin. ${ }^{12}$

Elimizde, olsa olsa, silinmiş olmakla beraber silik izi kalmış ama yine de okunmaya çalışılan, katmanların iç içe girdiği bir metin vardır. Bu bir ev-metindir çünkü anlatıcı veya

düşü veya ütopyası dediğimiz olgu da yolgeçen hanı deyimiyle karşılanabilir. Zira orada da eve giren çıkan belli değildir, kimin ev sahibi kimin konuk olduğu silikleşmiştir. İleriki sayfalarda bu konuya geri dönülecektir.

11 Kitabın üstünde yazarının adının bulunması ev sahibi kavramını öne çıkarmaktadır. Han Duvarları şiirinde anlatılan olayda olduğu gibi (masal ve destanlar için de geçerli) anonim olan, dolayısıyla yazarı belli olmayan daha doğrusu yazarsız metinlerde kimin konuk kimin ev sahibi olduğu belli değildir. Bu aşamada şu soruyu sormak da anlamlı görünmektedir: Anonim ürünleri mutlak konukseverliğin ölçütleri olarak da düşünebilir miyiz?

12 Gürbilek, bu düşüncelerini her ne kadar daha çok Gece için serdetse de Kılavuz'un bu tanımlamaya daha çok uyduğunu düşünüyorum. Gürbilek'in Bilge Karasu'nun metinlerinde kullanılan hayvan imgelerine yoğunlaşan bir çalışması için bk. Gürbilek. (2005). 
yazar, okurlarına karşı etik/konuksever davranmış ve onların tasarruflarını olduğu gibi yansıtmıştır. Uğur hem anlatıcı (Karasu'nun anlatıcısı) hem de yazar (kendi metninin yazarı) olarak anlaşılabilmektedir. Mümtaz Bey ve İhsan da hem okur hem de muhayyel muhatap olarak anlaşılabilirler. Dolayısıyla karşımızdaki etik bir yazar ve anlatıcıdır, denebilir.

Kılavuz'da da yazınsal politikanın izlerini sürmek mümkündür (Yazarın, burada Karasu, anlatıcıyı/yazarı/okuru/muhayyel muhatabı iç içe geçirmesi, aralarındaki hiyerarşiyi yok etmeye çalışması, birinin sıfatlarını diğerine yüklemesi; gerçek, kanlı canlı, nefes alıp veren, günlük hayatta var olan biz okurların da yazınsal dünyaya dâhil olabileceklerini (aşağıda dâhil olmaları gerektiğini göreceğiz) sezdirmesi kendi yazarlığını, "author" oluşunu; dolayısıyla otoritesini paylaşması, güçsüzleştirmeye çalışması politik bir tavırdır.). Fakat yazınsal politika meselesi daha çok Gece'yle birlikte düşünülebilir.

Gece gündelik anlamda politika gözüyle olduğu kadar yazınsal politika gözüyle okunmaya da oldukça elverişli bir kitaptır. Buna olanak sağlayan en önemli unsurlardan biri elbette metnin içine yerleştirilmiş dipnotlardır. Dipnotların anlatıcısının kim olduğu çok açık olmamakla beraber yazar onun Karasu olduğunu düşünmemizi ister gibidir. Aslında metin içinde yazardan söz etmek olası değil, dolayısıyla ona da anlatıcı demek daha isabetli olur. Anlatıcı, romandaki dipnotlarla Gece'nin yazınsal politikasını açıklar. Anlatıcı dışında dört ana anlatıcı vardır: Bunlara alt-anlatıcılar da denebilir. Anlatııı bilerek kendini dört alt anlatıcıya böler. 65. bölümdeki dipnotta anlatıcı, "Şimdiki durumda dörde bölünmüş olmam, ulaşmak istediğim simgesel kavrayıcılığı gerçekleştirmekte beni ne ölçüde başarılı kılar?" diye sormaktadır. Söz konusu dört alt anlatıcı N., O., Sevim ve Sevinç'tir.

Bu bölümde de görüldüğü gibi Karasu, anlatıcı kavramını silikleştirmeye çalışmaktadır. Akşit Göktürk yazdığı sunuş yazısında "Geleneksel yazı, yazar, anlatıcı, kişilik, öykü kavramları da bir değişikliğe uğratılıyor Gece'nin söylem serüveninde." (Karasu, 2004: 6) diye yazmaktadır. Gece'nin politikası geleneksel uzlaşımları sorgulamak, yeni birtakım olanaklar ortaya çıkarmak olarak ortaya konabilir. Söz konusu dört alt anlatı$\mathrm{Cı}$ arasında bir otorite çatışması var gibidir. Metnin kimi yerlerinde bu alt anlatıcılar birbirine karışır. Anlatıı herhangi bir karara varmamızı engellemeye çalışır gibidir. Göktürk, "'yazar'ın, 'yaratman'ın 'düzeltmen'in yaratı ile 'anlatıcı' ile sürekli yer değiştirmesi, birbirinin etkinlik alanına taşması, birbiriyle örtüşmesi, birbirinin bireyselliğini kırıp ortadan kaldırması, söylemin dalgalanmasında başlıca etken." (Karasu, 2004: 7) diye yazmaktadır. Karasu, asıl anlatıcı olarak, tüm bunların farkındadır. Anlatıcı, "dağınıklığı toparlamak gereği var, her şeyin ardındaki yazar ben miyim, benim bir yaratığım mı, kararlaştırmak gereği var..." (Karasu, 2004: 32) demektedir. Bu sözlerin sahibi anlatıcı ama "her şeyin ardındaki yazar ben miyim..." diyerek anlatıının yazarı ortaya çıkarma olasılığını da sezdirir ki bu, geleneksel uzlaşımlara zıt bir durum gibi görünür. Geleneksel olarak anlatıcıyı yaratan yazardır, daha doğrusu yazar kurgu dünyası- 
nın dışındadır. Burada sarmala bir daire daha ilave edilmektedir. Yazarın yarattığı anlatıcının başka bir yazar yaratması bir alt katmanda başka bir anlatıcıyı daha zorunlu hâle getirmektedir. Bu anlatıcının ise tek bir anlatıcısı yok; alt anlatıcılar olarak tanımlanabilecek dört anlatıcısı var.

Romanda farklı anlatııların anlatıları iç içe verilmektedir. Bu anlatılar bazen birleşip bazen ayrışırlar. 22. bölümdeki dipnotta anlatıcı "kiş̧ileri de hem var kılmalıyım, hem de belirsizlik içinde bırakmalıyım. Öyle düşünüyorum ya, gerçekte ne demek bu? Öznenin ara ara belirsizleştirilmesi..." (Karasu, 2004: 56) diye yazmaktadır. Anlatıcı metnin politikasını yine biz okurlara açıklamaktadır. Kimi zaman kişilerden biri tamamen ortadan kaldırılır: "Düzeltmen, Yaratman, Yazar, kitabın en başında kaldı. Bu gidişle onu bir daha anmayacağa benziyorum. Oysa ilk günler onu kendi "avâtara"larımdan biri diye düşünmüştüm" diye yazııır 30. dipnotta (Karasu, 2004: 70). Bu dipnotla, yazınsal politika açısından iki önemli bulgu verilir elimize. İlkin yaratman, düzeltmen ve yazarın aslında aynı kişi olduklarını öğrenmiş oluruz; anlatıcının "avâtara"sı olarak. İkinci olarak başta belirlediğimiz dört alt anlatıcının en azından isim düzeyinde bu "avâtara"nın ortadan kaldırılmasıyla ortaya çıkmış olduğunu. 39. bölümün alt anlatıcısı O., "Ona N. diyeceğim bundan böyle. Adının Naal, Nait, Nahi olmasının herhangi bir önemi kalmadığı için." der. Burada belirsizleşen, çoğalan, çoğullaşan öznenin ortaya çıkışıyla karşı karşıyayız çünkü anlatıcının ikiye bölündüğü, çoğaldığı burada bize anlatılmış olur.

Metnin sonlarına doğru N.'nin bir roman yazıyor olduğu ve Sevinç'le romanın gidişatı hakkında tartıştığını öğreniriz. Bu durumda N. ve Sevinç, alt anlatıcı vasıflarını koruyorlar mı belli değildir. İkisini de yazan birileri var çünkü Sevinç'in itirazlarını da N.'nin anlatısını da okur olarak görebiliyoruz.

Konukseverlikte ev sahibi, konuğuna karşı otoritesini silikleştirir, çünkü ona yer açmaIıdır. Levinas'ın deyişiyle "onun yüzüne alan bırakma"lıdır. Gece'de yazarın, düzeltmenin, yaratmanın, anlatıcının ve alt anlatıcıların birbirlerini sildiklerine, otoritelerini kimi zaman paylaştıklarına şahit oluruz.

Konukseverlik tartışmalarında Derrida'nın üzerinde pek durmadığı bir konu daha var: Derrida ve genelde konukseverlik tartışmaları ev sahibini odağa alan tartışmalardır. Konuksever bir ev sahibinin, ülkenin veya herhangi bir mekân sahibinin nasıl olması gerektiği kısaca tartışıldıktan sonra konumuz bağlamında kısaca tartışılması gereken bir konu daha var: Konukseverlik düşüncesinin mantıki diğer boyutu olan konuk ve konuğun etik tavrı.

Bu konuda akla gelen soru şudur: Peki, bir yere konuk olmuş ve mutlak bir konukseverlikle karşılanmış (mümkünse eğer), en az mekân sahibi kadar kendine karşı etik bir konuk, nasıl davranmalıdır? Mutlak konukseverliğe muhatap olan bir konuk kendine karşı olan etik tutumundan dolayı ev sahibinin açtığı alanı, ona/onun yüzüne açtığı alanı doldurmalıdır. Bu bir dayatma veya kural/yasa değildir. Sadece konuğun etik tav- 
rıdır. Ev sahibi (Ihssan ve Uğur'un Yılmaz Bey'in evine ilk gidişlerinde olduğu gibi) konuğu oturma odasına hapsetmez. Konuğa mutfağa, banyoya, evin diğer odalarına girme olanağı tanır. Bu olanak tanıma, sözle yapılan bir edim değildir. Ev sahibi onlara böylesi bir hakları olduğunu hissettirir. Böylesi bir etikle, konukseverlikle karşılaşan konuğun da etik davranış olarak mutfağa, banyoya ve evin diğer odalarına serbestçe girebilmesi gerekir. Bu neredeyse ev sahibinin değil ama konuğun kendine dayattığı, bir zorunluluk hâlini alır.

Metinsel konukseverlikle bu durumu bağdaştırdığımızda şöyle düşünebiliriz: Kılavuz veya Gece, Cem İleri'nin gösterdiği gibi, çok katmanlı metinlerdir. Gerçeklik düzleminden kurmaca düzlemine yani yazınsal konukseverliğe şöyle bir analojiyle geçilebilir: Kılavuz veya Gece de birer ev olmakta, biz okurlar da o evlere davet edilmiş konuklar olmaktayızdır. Söz konusu romanların her bir katmanı evin her bir odasına denk gelmektedir. Dolayısıyla etik bir konuk olarak biz okurların evmetne girmesi, ev-metnin odalarını gezmesi gerekmektedir. Ev sahibi ya da yazar, odalara girmediğimiz için bizi kınamaz veya girmemizi dayatmaz ama diğer odaların, banyonun, mutfağın, evmetnin katmanlarının izlerini bize gösterir. Onun gösterdiği, ima ettiği izleri sürmek, ev-metnin katmanlarının izlerini sürmek etik bir konuğun yapması gereken bir eylem hâlini alır. ${ }^{13}$

Dolayısıyla konuksever bir anlatının etik okurları olarak metni anlamaya çalışmak yani yüzümüze gösterilen konukseverliğin hakkını vermek gerekir.

Elinizdeki makale mutlak konukseverlik düşüncesinin sınırlarında sorulabilecek birkaç soruyla sonlandırılabilir: Yazının başlarında Derrida'nın konukseverliği olabildiğince geniş düşündüğü dile getirilmişti fakat Derrida'nın konukseverlik düşüncesiyle ilgili birtakım sorular akla gelmektedir. Acaba insan, kendi kendinin konuğu olabilir mi? Bedenimize konuk olmuş olabilir miyiz, bedenimizin maliki miyiz? Yoksa dinî terminolojide dile getirildiği gibi bedenimiz, bize emanet mi? İnsanın kendisini yeryüzünde daha doğrusu dilde konuk olarak görmesi, konukseverlik düşüncesi açısından mümkün mü? Bu bakış açısından mutlak konukseverliği, ev sahipliğinin, mülkiyetin ikinci plana düştüğü bir çerçevede incelemek olası mıdır? Son olarak da Derrida ya da konukseverlik düşüncesini ortaya atan düşünürler, konukseverlik karşıtı ya da düşmanı bir fikri zihinlerine buyur edebilirler mi? Bunlar ve bunlara benzer soruları, yazmayı planladığım ve bu yazının devamı niteliğinde olacak başka bir makalede ele alabilmeyi umuyorum. ${ }^{14}$

Sonuç olarak Bilge Karasu'nun Gece ve Kılavuz adlı romanlarını incelemede/anlamlandırmada (yazınsal) konukseverlik kavramının oldukça faydalı bir enstrüman olduğunu söylemek mümkündür. Karasu, hem okuruna hem de kahramanına karşı etik bir

13 Konuksever bir metnin eleştirmeninin yapması gereken de bu mudur acaba sorusu, bu konu bağlamında tartışılması gereken/tartışılabilecek konulardan bir diğeridir.

14 Bu ve benzeri soruları sormama yardımcı olan Özkan Gözel'e tekrar teşekkür ederim. 
duruş sergilemiştir. Enis Batur (1997: 162)'un da dediği gibi “Bilge'nin anlatı dünyasında Ahlak baş köşeyi tuttu" Derrida'nın bir adım ileriye taşımış olduğu konukseverlik düşüncesi, Bilge Karasu romanlarını hem etik (Kılavuz) hem de politika (Gece) boyutuyla düşünmemize olanak sağlamaktadır.

\section{Kaynakça}

Açıl, B. (2009). Osmanlı Mesnevilerinde Anlatıcı Olarak Gelenek: Hüsn ü Aşk Örneği. Kritik, 3, 148165.

Akatlı, F. (1997). Çağdaş bir penelope. Akatlı, F. ve Gürsoy Sökmen, M. (Ed.), Bilge Karasu aramızda içinde (s. 115-123). İstanbul: Metis.

Batur, E. (1997). Bilge Karasu üzerine iki not. Akatlı, F. ve Gürsoy Sökmen, M. (Ed.), Bilge Karasu aramızda içinde (s. 160-163). İstanbul: Metis.

Bernasconi, R (2004). Levinas ve ötekilik politikası (çev. Z. Direk). Tezkire, 38-39, 110-125.

Chantal, M. (drl.) (1998). Yapıbozum ve pragmatizm (çev. T. Birkan). İstanbul: Sarmal.

Derrida, J. (1999). Pera, peras, poros (hzl. F. Keskin ve Ö. Sözer). İstanbul: YKY.

Derrida, J. (2008). Çile (çev. M. Başaran). İstanbul: Kabalcı.

Derrida, J. ve Duformantelle, A. (2000). Of hospitality (trans. R. Bowlby). Stanford, CA: Stanford University Press.

Direk, Z. (1997). Konukseverliğin düşüncesi. Defter, 31, 11-36.

Direk, Z. (1998). The renovation of the notion of experience in Derrida's philosophy. Unpublished doctoral dissertation, The University of Memphis, Memphis.

Gürbilek, N. (1995). Yazı ve arınma. Yer değiştiren gölge içinde (s. 69-93). İstanbul: Metis.

Gürbilek, N. (2005). Büyümenin tarihi. Ev ödevi içinde (s. 77-92). İstanbul: Metis.

İleri, C. (2007). Yazııın da yırtııverdiği yer. İstanbul: Metis.

Karasu, B. (2004). Gece. İstanbul: Metis.

Karasu, B. (2006). KIlavuz. İstanbul: Metis.

Levinas, E. (1969). Totality and infinity (trans. A. Lingis). Pittsburg, PA: Duquesne University.

Levinas, E. (2003). Humanism of the other (trans. N. Poller). Urbana and Chicago, IL: University of Illinois.

Naas, M. (2006). "Alors, qui êtes-vous?" Jacques Derrida ve konukseverlik sorusu (çev. E. Simson). Cogito, 47-48, 236-250.

Özata Dirlikyapan, J. (2008). Yazının da yırtılıverdiği yerde "gösterilmeyen" kaynaklar. Virgül, 123, 47-49.

Stocker, B. (2006). Derrida etiğinde çelişki, aşkınlık ve öznellik (çev. Ö. Ejder). Cogito, 47-48, 334347. 


\title{
Literary Ethics and Politics: A Hospitable Approach to the Novels by Bilge Karasu
}

\author{
Berat Açı ${ }^{*}$ \\ Keywords: Bilge Karasu, Derrida, Hospitality, Home-text, literary hospitality
}

What is the relationship between theory and daily life (practice)? Are they totally exclusive or do they have any commonalities? This article argues that the thought of hospitality is able to be used as an instrument in which theory and practice complement each other. This article will first examine Jacques Derrida's theory of hospitality and then will evaluate Bilge Karasu's novels (Gece [Night] and Kılavuz [Guide]) in the light of this theory of hospitality.

Although hospitality has been firstly conceptualized by Emmanuel Levinas, it has further been developed by Derrida. Hence, there are some differences between Levinas' and Derrida's concepts of hospitality: firstly, the subject of hospitality is the human being according to Levinas whereas for Derrida, it is not a necessity to be a human being in order to be a subject of hospitality. The subject of hospitality can be an animal, an angel, and even a ghost. Secondly, Derrida says that we can be hospitable to a man that we do not even know but for Levinas the object of hospitality must be a familiar one, or at least we must know his/her name. Thirdly, for Levinas a hospitable person should have some possession to bestow to the guest while there is no need for such an imperative according to Derrida. Still, there are two inherent parts of hospitality, both for Levinas and Derrida: ethics and politics. The first one occurs in the relationship between the self and the other. Nonetheless, politics emerge in the relationships among at least three persons, which constitute the realm of the politics.

The main problem of the hospitality according to Derrida is having the status of being an "alien" or "the other" for the subject of the hospitality, but who is "the other"? Determining or labeling someone else as other, logically, includes the relationships of family, nation, state and citizenship into this equation. The solution Derrida proposes for that problem is not to ask the arriver anything, even his/her name. This is a practice for which Derrida says "the experience which is possible in shores of impossibility".

* Yrd. Doç. Dr., İstanbul Şehir Üniversitesi Türk Dili ve Edebiyatı Bölümü. 
We can think about three types of hospitality in Bilge Karasu novels: first, is the deadly hospitality seen in one of his stories "Avından El Alan", which is not the subject of this article. Second, is the blurred hospitality seen in his novel Kılavuz. And third, is the dream of hospitality in Gece, which can also be conceptualized as the utopia for hospitality.

Kılavuz is a novel, which seems to be written to exemplify the notion of hospitality. This novel will be evaluated as a sample work on the representation of the ethical aspect of hospitality. All events happen in one house in Turunçlu. There are four characters in a way live in that house which belongs to Yılmaz Bey. Mümtaz Bey, the uncle of Yılmaz Bey, is the permanent guest; Uğur, is the temporary guest who came to accompany Mümtaz Bey; and lastly, Ihsan is a coming-going guest who has a homosexual relationship with Uğur and who is the devoted taxi-driver of Yılmaz Bey. It is observed that, in the novel, Yılmaz Bey is a hospitable owner who acts as a guest in his own house. He never sleeps at his home. Other guests use the house more than him. One of them, Uğur, was accepted to home, to put in Derrida's words, with even not being asked of his name. In terms of the relationship between characters, KIlavuz is a good example of virtually absolute hospitality as all characters behave each other in an ethical manner .

By investigating Kılavuz with respect to literary hospitality, it becomes possible to claim that there exists an ethical relationship between the narrator, the narratee, the author and the reader. The narrator of Kılavuz is Uğur; who writes his diary but accepts redactions or re-writings from Mümtaz Bey and İhsan. They are guests to the text of Uğur which can be named as home-text. Both Mümtaz Bey and İhsan make corrections on the text of Uğur. As the narrator (in another level, host) Uğur, permits them to change his diary. That is because a hospitable host should allow his/her guests to behave freely. This intervention augments and enlarges the text. According to the literary theory, the involvement of Mümtaz Bey and ihsan makes the text multilayered.

Gece can be analyzed as a work examplifying the political dimension of hospitality. In the novel, a chaotic situation is narrated. In the narrative, someone call "the workers of the night", to re-organize or de-organize all the streets in such way that a passenger cannot find the end of the street. Arriving at the end of the street one sees that the next street is located three meters down or five meters up. So the passenger should walk back to the beginning of the street to pass another one. There is another danger, for it is said that after dusk falls the passenger outside is killed. The solution to that problem is ipso facto found by the existence of the "guest houses" where after the nightfall everyone is accepted. In one of that "guest houses", there are about fortyfive people none of whom knows who is the host. It is possible to call this situation as absolute hospitality. 
Theoretically, there is a guest and a home. Thinking about literary hospitality, constituents turn to be a text (home) and a reader (guest). The reader is the guest in the text. As the subject here is the fiction itself, we should analyze the narrator and the narratee. So the narrator is the hospitable host and the narratee is the guest. The narrator should permit the narratee to behave freely on his text as Uğur in Kılavuz does. Kılavuz is the home-text in which both the host's and the guest's deeds are ethical. As mentioned earlier, we cannot determine who the owner of the home-text is; this is a sign of absolute hospitality. Therefore, it can be argued that Kılavuz is an example for the ethical aspect of hospitality.

On the other hand, Gece can be treated as an example for the political dimension of hospitality. There is no single narrator in the novel. The main narrator is divided into four sub-narrators: These are N., O., Sevim and, Sevinç. Bilge Karasu, intentionally, wants to blur the concepts of both the writer and the narrator. The narrator calls these sub-narrators as his / her "avatara"s. In this novel, it is observed that the host (author) diminishes his / her authority as it should be done in/by hospitality.

The point that should be underlined is the ethical attitudes of the guest against his / her hospitable host, which is not mentioned by Derrida. How should a guest, who is welcomed hospitably, behave accordingly? Although the host does not tell the guest to enter all the rooms of the house, a guest whose deeds are ethical should enter the other rooms. To create the analogy between real hospitality and literary hospitality, it can be argued that we as the readers should enter all the rooms of the text to criticize all parts of the text by pursuing traces posited by the writer to the text. This is a task, which must be accomplished by the critics.

Consequently, we can argue that Bilge Karasu is a hospitable writer, both ethically and politically as exemplified by his novels Kılavuz and Gece, respectively. 